\title{
Refuge or Asylum A Philosophical Perspective
}

\author{
HOWARD ADELMAN \\ Refugee Documentation Project York Univarsity \\ Ontario, Canada.
}

Even if a state has the absolute sovereign authority to control the entry of refugee claimants, and that absolute sovereign authority is based on the obligation of the state to serve the self-interest of its members, nevertheless that absolute sovereignty must be qualified to grant rights to arrivals who are refugee claimants. This conclusion follows:

a) logically from the premises of such a state, since such an extension recognizes the priority of self-jnitiated actions over bureaucratic ones;

b) from the necessity to give witness to the fundamental values of a state based on self-interest;

c) as a litmus test of whether a state is indeed based on individual self-interest;

d) from the necessity to preserve international order, which is in everyone's selfinterest.

The paper then argues that a western liberal state does not, however, have absolute sovereign authority, not only with respect to its own members, particularly in areas such as providing aid to refugees, but also with respect to stateless individuals or individuals who come from states which have failed to provide protection. Such individuals have rights which qualify the absolute authority of a state.

\section{Redefining Asylum}

Traditionally, there are three and only three durable solutions to the problem of refugees: first, voluntary repatriation to the country from which the refugee fled; second, settlement and integration in the country of first asylum; and third, resettlement in a country abroad.

Asylum in international law is generally seen as a contrast with a durable solution for refugees in that it is temporary. Thus, refugees in Thailand from Indochina have received asylum, i.e., temporary refuge, until they can be resettled abroad or repatriated to the country from which they fled. Asylum is also used to refer to the treatment accorded non-Convention refugees, that is, refugees who cannot qualify under the international Convention as capable of 
personally establishing a well-founded fear of persecution. They may simply be fleeing wanton killing and indiscriminate violence, compulsory military service in a war they did not support (American draft dodgers and deserters), or may have been subjected to coercion and intimidation but not outright persecution. These are sometimes referred to as Humanitarian in contrast to Convention refugees. (Humanitarian refugees have many designations; for example, in Sweden they are called B refugees, whereas in Canadian law they are referred to as designated class immigrants.)

One no sooner makes these tidy abstract distinctions than they begin to fall apart. Originally, temporary refuge or asylum was viewed as an interim step whereby a state accepted the principle of non-refoulement - that is, not forcing an individual to return to the state from which he fled where his life might be in danger - but where the state did not want that individual as a permanent member of the political community. Temporary asylum was therefore relevant only where repatriation or resettlement abroad was a prospect in the foreseeable future. When the prospect of repatriation became more and more remote, and camps filled up faster than resettlement of fers could empty them, then asylum led to the creation of a permanent class of refugees. The vision of Palestinians, many of whom, forty years after the original conflict, are still without membership in a state which guarantees their protection, haunts the international community. The result is that countries of first asylum, such as Thailand and Hong Kong, adopt programmes of 'humane' deterrence to discourage new arrivals and to encourage those already present to risk repatriation. They resent the resettlement countries, who have skimmed the cream and left the aged, crippled, psychologically disturbed, ill, and illiterate as a problem for local authorities - countries with the least economic capability of handling them. Three-quarters of all refugees in the world have been in a situation of temporary asylum for over five years (Stein 1967).

The following diagram (Figure 1) depicts the situation.

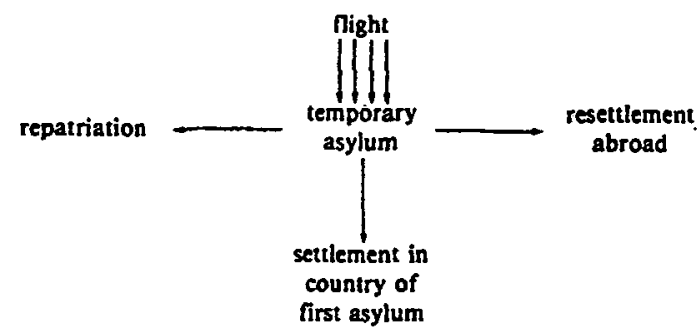

Figure I: Asylum, The Constraint on Outputs

The result of this build-up in the middle is like a pressure cooker where the pressure from inputs is much greater than the release outlets. In many cases, 
the result is the creation of explosive forces which threaten further destabilization to the international order.

The pressure cooker produces effects on all countries providing different durable solutions - including countries which contribute to the permanent solution of the refugee problem by offering opportunities for resettlement. Canada, for example, defines itself as a country of resettlement in contrast to a country of first asylum. Canada responds to the pressure cooker by trying to limit the spontaneous arrival of refugees. One Canadian method is to impose visas on entrants from refugee-producing countries as well as on entrants from countries which, though they do not produce refugees, are sources of refugee claimants (Portugal, for example). This can be documented by the history of Canadian legislation, the discussion behind that legislation, the parliamentary debate in the legislature, explicit government statements by the minister in charge, the analysis of legislation itself, explicit patterns of decisions reaffirming Canada's role as a country of resettlement in contrast to a country of asylum, and, most clearly, specific programmes, such as the imposition of visas. The attempt to control the spontaneous arrival of refugees can be rationalized as more efficacious on a humanitarian level in that refugee claimants within Canada cost three times as much to process as those Canadians select abroad. It can also be said to be fairer. Refugees who are persistent and innovative (and who are overwhelmingly male) dominate the spontaneous arrivals into Canada; in camps, women and children predominate, and they and others in the camps rarely have the resources or the independence to make Canada a country of first asylum.

The effect of spontaneous arrivals in countries which define themselves as resettlement countries and which do not want to handle spontaneous arrivals, is to give a new twist to the meaning of asylum. Asylum has become another route to a durable solution. Loescher and Scanlan (1986: 78) use the term this way, 'Haitians found the principal barrier to formal or informal asylum was the progressively cozier relationship between the United States and the government of Haiti.'

For countries adjacent to refugee-producing areas (Thailand and Pakistan), asylum comes to mean the acceptance of permanent refugees under the language of temporary asylum; for first world countries, like Canada, it comes to mean providing another avenue for a durable solution, but one in which the initiative is taken by the refugee and not by the sovereign state of Canada. In third world countries, asylum means de facto but not de jure permanent status. In first world countries, such as Canada, it often implies using de jure opportunities to establish Canada as, de facto, a country of first asylum even if it is reluctant to define itself de jure as one. Hence the tremendous debate in Canada over the refugee status determination procedures which allow refugee claimants to come directly to Canada to have their claim vetted independently of the refugee selection system.

In sum, for settlement countries (e.g. Thailand), asylum means permanent settlement (because of mass movements), in spite of the overt policies of settle- 
ment countries to provide only a temporary solution. In resettlement countries (e.g. Canada), asylum means permanent settlement (because of individual initiatives) in spite of the overt policies of the receiving country to limit the number of opportunities for spontaneous arrivals.

A parallel shift has taken place in repatriation. A closer look at the repatriation experience indicates that an informal process has gone on independently and in spite of the formal process of repatriation (Stein, forthcoming), because the formal processes provided added risk rather than added protection. As a result, asylum comes to mean permanent refuge, rather than temporary refuge, and a refuge determined by the initiative of the refugees in spite of the policies of the refugee-receiving countries.

The issue of asylum versus refuge, previously considered to be one of temporary versus durable solutions, needs to be recast in terms of empirical realities. (For the contrast is one that serves official international policy makers and those concerned with formal legal procedures.) The old framework of temporary versus durable solution does not reflect the more relevant and quite different de facto contrast between refugee-initiated solutions and state and inter-state-initiated and sanctioned solutions. The problem of asylum, whether in countries of repatriation, countries of first settlement or countries of resettlement, is not one of temporary versus durable, but one of less durable, more tentative solutions that are refugee-initiated versus formally durable solutions that are sanctioned and endorsed by states. The old contrast of temporary versus durable allows the official international policy makers and those preoccupied with legal procedures to avoid dealing with the reality of individual refugee initiatives, on the one hand, and state power which prevents a formally sanctioned solution of a refugee situation, on the other hand.

The general problem must be placed in a theoretical context of state sovereignty, and specific refugee policy in a concrete context of the foreign policy of a particular country related to the domestic attitudes of its citizens. Rapid changes in technology and transportation continually challenge those countries which want absolute sovereign control over who can and who cannot enter a state as a prerequisite to becoming members of those states. At the same time, the traditions of church sanctuary in tandem with the human rights movement have provided an historical, intellectual and moral basis for challenging the concept of the absolute sovereignty of the state.

Thus, asylum versus refuge as options come to mean not temporary versus permanent, but individually initiated solutions versus those sanctioned and controlled by the state. It is this philosophical debate that will be discussed in this essay.

Qualifying Sovereignty

Michael Walzer (1983: 31) noted: "Ihe primary good that we distribute to one another is membership in some human community.' In granting membership 
in the political community known as the state, three different issues can be considered. First, is it or should it be the absolute prerogative of the members of that state, through the elected representatives, to decide whom to admit and whom not to admit as members? (The question refers, of course, to democratic states in which, rooted in a social contract theory of the state, the governing body acts on behalf of the citizens and not in its own interests.) Secondly, if that absolute sovereignty is to be qualified, who qualifies it? Thirdly, on what grounds should that sovereignty be qualified? The three issues are linked. The first issue is about absolute versus qualified sovereignty. The second issue is who has the authority to qualify it. These first two issues are rooted in the larger one of the grounds for acceptance of new members in a state. Does the authority for making the decision rest wholly within the bounds of the members of the state, or can sovereign decision making authority be qualified in some way by granting inalienable rights to non-members of a state to make claims for membership in that state? What are the grounds for granting such rights to non-members? Does an international authority, or international norms and moral standards play any role in granting such rights? When the underlying philosophical issue is approached (rather than analysed), it is usually cast in terms of the first issue above - absolute versus qualified sovereignty. In some assessments developing the issue a little further (GrahlMadsen 1966), absolute sovereignty is identified with a positive approach to law, and qualified sovereignty with a view of law bounded by moral precepts, such as human rights, international responsibilities and responsiveness to civilized sensibilities. Therefore, even when these issues - whether absolute sovereignty should be qualified, who can qualify it and on what grounds - are touched upon, the question is begged whether absolute sovereignty should or should not be qualified. The arguments for justifying qualified sovereignty (or absolute sovereignty, for that matter), simply shift focus to the debate between a view of law as a convention rooted in self-interest (a relativist view of law) versus a view of law rooted in and governed by moral precepts. The relativist view of law is allied with absolute sovereignty. By its very nature, it is indifferent to the welfare or interests of others (non-members of the state) who do not make the law. The view of law rooted in a higher universal morality of some sort is linked with qualified or relative sovereignty.

Unless the arguments for qualifying sovereignty, or for restricting absolute control to members of the state, are unpacked and examined, the issue of whether or not to grant greater room for the self-initiative of refugees to determine an acceptable solution for themselves will remain a matter of taste rather than one of intellectual judgement.

Should sovereignty be absolute or qualified? To answer this, we can shift to the second issue - who can qualify absolute sovereignty? The usual assumption is that the issue involves demarcating which non-members (usually a very, very small group) have the right to qualify the absolute character of sovereignty. But it can be argued that only the members of the state have the right to qualify absolute sovereignty, and that they ought to do so on moral grounds. 
That is, if members of a state have the absolute power to qualify that power, they ought to qualify it because of overriding moral requirements.

I want to make a much stronger case. I want to argue that not only can the initiative to qualify absolute control come from the state that has it, but the very premises of absolute sovereignty argue for, if not dictate, such a qualification. In other words, the premises of absolute sovereignty push for and even dictate qualified sovereignty. Absolute and qualified sovereignty are not polar opposites; qualified sovereignty is a logical product of the principles of absolute sovereignty when applied to particular existential situations.

\section{Self-Interest as the Basis for Qualified Sovereignty}

The premise of absolute sovereign control over who should or should not be members of one's political community is generally considered to be selfinterest. Only the members of a state can determine whom to admit or not to admit into membership on the basis of the collective self-interest of the existing members. Thus, for example, Canadian foreign policy was deliberately shifted from the perspective of the Pearsonian goodhearted international broker to a policy based on self-interest during the third majority rule of the Liberal Party under Pierre Elliot Trudeau (see, for example, Dewitt and Kirten 1983, Gwyn 1980).

The first set of arguments which I wish to put forth accept that the principle of absolute sovereignty is rooted in self-interest, but argue that self-interest argues for and even dictates qualifying that sovereignty. Four arguments can be considered supporting the position that it is in the collective self-interest of existing members to qualify their own absolute sovereignty and allow a selfinitiated refugee to contribute to the determination of a membership claim.

The first argument is that it is a logical extension of the principle of selfinterest. For if the state is given absolute control over membership issues, then the reality is that such authority will be wielded by bureaucrats. An assumption is made that any increase in the authority of bureaucrats tends to lessen the chance that the authority will be wielded in the self-interest of the citizenry. The result will be a decline in the initiative and responsibility of individual citizens which the state was designed to enhance, not inhibit. There may be a conflict between the pursuit of self-interest, as the basis for the creation of the state, which the authorities of the state are there to protect, and the fact that those same authorities, in the name of protecting the individual citizens, will arrogate that authority to serve their own interests and develop a monopoly on power. That is, rather than using their formal authority to assess the degree to which a decision fosters the self-interest of the citizens, they will refer to and use references to fears, mostly irrational, of a segment of the citizenry to enhance their own control over who should or should not be a member of the nation-state. It may in fact be the case that spontaneous arrivals who are not selected by a bureaucracy but who nonetheless meet a set of norms and fulfil certain principles of the state will become as good if not better members than those chosen by a bureaucratic state. Those who demonstrate the determina- 
tion, initiative and perspicacity to find the means to arrive in a country like Canada to make a refugee claim (as distinguished from those selected abroad), or those who manage to settle and prosper in a country of first asylum without official support, or those who manage to repatriate on their own, are the very individuals that a country wants as its members if the country is based on a philosophy that it is constituted because of the self-interests of the individuals who make up the state and was created to enhance those self-interests. Individuals who demonstrate the best initiative in protecting and ensuring their own personal survival are ideal targets for inclusion in a state rooted in a principle of self-interest. To summarize, qualifying absolute sovereignty is not only consistent with but also a logical extension of the principle of selfinterest.

The second argument suggests that taking in refugees as a matter of their right is not simply a logical extension of the state constituted to serve and enhance the self-interests of its members, but is a way of giving witness, of demonstrating the principles of such a state in contrast, for example, to those states ostensibly dedicated to the welfare of the citizenry as a whole. Countries founded to serve and enhance the self-interest of their members contrast with those states constituted not to serve the individual self-interest of their members but rather the collective self-interest defined by a small core within the leadership. In other words, it is not surprising that it is countries with a democratic liberal tradition (in contrast to Marxist-Leninist states) which grant refugees the right to claim status. Such a stance exemplifies, in the highest sense, the premises of a state set up on the basis that there was an implicit social contract among its members, and that the state exists to serve those members and not some idea of justice in the eyes of a few. Opening one's doors to the claims of individual refugees exemplifies in the best way possible that the state exists to serve individual self-interested claims and not abstract principles of justice articulated by an elite.

Qualifying absolute sovereignty, thirdly, is, in fact, a litmus test of whether a state is truly a social contract state or one in which a benign leadership determines what is in everyone's self-interest. In other words, granting rights to individual refugee claimants not only is a logical extension, not only is an existential expression of a subjective set of beliefs, but also provides an objective standard by which to assess and judge the degree to which a state truly adheres to such principles.

Finally, it is in the self-interest of a state and its members to preserve international order. In a world in which there is effectively no territory left which is not under the jurisdiction of a state and, therefore, where it is no longer possible to flee to a new land where a new social contract can be devised, it is in the interests of existing states to ensure that every individual who lacks the protection of a state has an opportunity to gain such protection. The preservation of international order is in the self-interest of any state. Since self-interested states will by their very nature tend to acknowledge the risk of disorder only when crisis is upon them, it is better for individuals who lack the protection of 
a state, and who could become an explosive force, to seek out that protection themselves when it is 'not granted freely. The alternative is, by inaction, encouraging the stateless to set off explosives to demonstrate that no one can have the protection of a state as long as that protection is denied to them.

All these arguments accept the premise that a state has absolute sovereign control over who can and who cannot become members of that state. Assuming a liberal, democratic, absolute sovereign state based on an implicit social contract among its members to serve and protect their self-interests, it is in their interests to qualify that absolute sovereignty and allow some individuals who are not members to seek membership as a matter of right rather than simply an extension of privilege.

\section{The Social Contract and Qualified Sovereignty}

The above set of arguments presume that absolute sovereignty is a consequence of a state constituted by the social contract of its members, but the premises of the contract dictate that those same members decide to qualify that sovereignty. The following arguments suggest that a social contract state does not lead to a concept of absolute sovereignty in the first place, but inherently qualifies that sovereignty. In sum, we argue that absolute sovereign control over membership is in fact not even inherent in the character of a state.

The first argument notes that if you accept that absolute control over membership is a prerogative of states, then it follows logically that states not only decide who can and who cannot become members, but also can expel existing members. Further, the state can prevent a member from leaving. For if members in contracting to form a state have delegated absolute control over future membership to that state, then that absolute control governs not only entry criteria but also exit criteria, including both forceful expulsion and the prevention of members from leaving. Since liberal states are generally granted the authority over admissions but not authority over exit for bona fide. members of that state (with the exception of those deemed to have committed a criminal act who may be prevented from leaving), then states based on liberal premises cannot have an absolute sovereign control over membership. Rather, sovereign control is at best restricted to new admissions, for: 'The restraint of entry serves to defend the liberty and welfare, the politics and culture of a group of people committed to one another and to their common life. But the restraint of exit replaces commitment with coercion' (Walzer 1983: 39). If we then grant that a state does not have absolute sovereign authority over membership but only absolute sovereign authority over the admission of new members, is that sovereign control subject to any qualifications? Another argument for such qualification goes back to the premise of a state assumed to be based on a social contract. There are really three key terms to that social contract. First, the function of the state is to protect the individual interests of its citizens without infringing on any rights that they did not surrender to state authority. This premise has already been discussed. But there.are two others. The state is granted a monopoly on the use of coercive power. Thirdly, the 
state has dominion over a particular segment of territory on the planet earth in which its citizens may enhance their well being.

Note, the only monopoly given to the state is the use of coercive power. The only area in which the state has ultimate dominion is its own territory. Territorial dominion is not simply a product of the efficacious use of the coercive power by the state, that is, a product of the use of force by a state, but is also a result of a recognition of those boundaries by other states. If boundaries depend on recognition by others, such recognition is not granted in an unqualified way. Recognition of boundaries does not grant absolute control over entry because the recognition of boundaries is subject to everyone having a place to live once all the territory on earth has been divided up among the states. As long as individuals are left who do not have a place to live and a state to protect their self-interests, no state has absolute control over entry-into its territory even though it has absolute dominion over that territory.

Thus, the absolute sovereignty of a state with respect to membership is restricted in at least two ways: the sovereignty applies to entry into membership and not exit from it. Secondly, the sovereignty is subject to the condition of controlling entry of bona fide members of other states, but not of individuals who do not have membership in any state. In other words, absolute sovereignty with respect to membership is qualified with respect to its own members and with respect to individuals who are not members of any states.

What about members of states which do not fulfil their function of protecting their members? Have these people been thrust back into a state of nature where the state, in breaching the implicit social contract, has made them de facto stateless if not de jure? From this perspective, the sovereignty of a state is qualified for individuals who lack either de jure or de facto membership in another state.

A third challenge to the assumption of absolute sovereign control bears more on the right to protection within a state for non-members than the right of entry into the territory. The issue is posed by institutions that are part of the society of that state. For though individuals may have granted the state a monopoly in the use of coercive force and a dominion over the territory of that state, subject to recognition by other states, the state was granted neither a monopoly to protect its citizens nor absolute dominion to ensure that protection was carried out. Monopoly over the use of coercive force does not entail monopoly over protection. Dominion over territory does not entail dominion over citizens. Though the state has a function to protect and enhance the welfare of its citizens, this function is not the exclusive prerogative of the state, nor was the state given dominion status over all other communities which serve to protect citizens.

In other words, a monopoly over coercive force and dominion over territory do not extend these areas of absolute sovereignty into a monopoly in and dominion over the protective function. Since the state does not have a monopoly or dominion over the protection of its own citizens, it certainly cannot monopolize or dominate the protective function extended towards non- 
citizens. Thus, if institutions, such as churches, have played an historic role of protection - in this case, providing sanctuary to those whose lives were in danger - then the sovereignty of the state cannot limit the protection those institutions offer non-members, unless the state can demonstrate that those non-members pose a threat to the interests of existing members or are an economic burden upon the public at large. But if the non-members are supported and protected by a church, for example, then the state may not have the absolute sovereign authority to deny those individuals that protection by institutions which may historically predate the creation of the state.

Finally, in the original social contract implicit in the creation of a liberal state, the powers surrendered to the state were limited. In some states (the U.S.A.) even the monopoly on the use of coercive force was qualified so that individual citizens retained the right to bear arms for their self-protection. Whatever the variations in different states on the limited powers and authority surrendered to that state, in no state did individuals surrender their human rights on becoming members of a state. For these were not just rights that individuals chose not to surrender; they were rights that were inherently theirs and could not be surrendered. Consequently, though Bills of Rights may or may not be included in the constitutions of all states, the sovereignty of all states is always subject to the limit that states cannot infringe on anyone's human rights. Since the very nature and creation of the state recognized that it is the right of every human being to have a place to live, then any individual, and not just members of a state, have the right to claim a place to live within that state provided that right has not already been both exercised and recognized elsewhere. Therefore, it is the duty of every state, in recognition of the rights of humans, to set up a judicial process to adjudicate fairly any claims for the exercise of such rights, that is, individual rights to a place to live in a state which provides protection from persecution. This does not entail that the state guarantee a productive livelihood or an income. Economic migrants will not have rights to make a refugee claim.

\section{A Perspective on the Arguments}

Two very different but complementary criteria have been offered to establish that the alleged absolute sovereignty of a state ought to be qualified on the grounds of self-interest and is, in fact, already qualified when the bases of a social contract state are examined. Further, these criteria elaborate the grounds for that qualification. One set of grounds was based on examining what it meant for the state to function solely on self-interest principles. The second set of criteria argued essentially that, whether or not self-interest of its members was the premise upon which a state was created, the powers of that state were definitely circumscribed with respect to the aspects of membership over which it could exercise sovereign control (entry versus exit) and with respect to those individuals over whom it could exercise such absolute control (only individuals who were members of other states and were protected by those states could be absolutely rejected). Further, the protective function was 
neither the state's exclusive mandate nor did the state have absolute dominion over other institutions in society that performed protective functions. Finally, all such protective functions and controls over entry were subject to the recognition of the rights of all men qua human.

These arguments are not new. However, they have generally been cast simply in moral terms. For example, states are urged to respect the sensibilities of their own citizens without defining what those sensibilities were that placed limits on the power of the state or why they should be recognized for having that effect. The argument that a state had international responsibilities under international conventions did not elaborate precisely what those responsibilities were to individuals who were not its own citizens or why the state had or ought to have such responsibilities. Sometimes the arguments were even more vague and abstract, appealing to the responsibility of a state qua civilized, without demonstrating that the nature of a civilized state requires that state to recognize that, in the development of civilization, the family and religious institutions (to name just two) have played and will continue to play a role in the protection of individuals. A state qua civilized cannot presume to have exclusive control and dominion over protective functions. Finally, traditional organizations such as churches, and new ones, such as Amnesty International, with a primary concern for human rights, have every right to challenge states and insist that the responsibilities of a state are always subject to a respect for human rights.

\section{Evaluating Qualified Sovereignty}

When we evaluate this qualified sovereignty in opposition to claims for absolute sovereignty, we find three sorts of arguments to reinforce absolute sovereignty at the expense of qualified sovereignty.

The first argument is based on historical precedent. It always boils down to the fact that states have traditionally always resisted any modifications to the controls they already exercised. This is the point behind the argument that Canada traditionally regarded itself as a country of resettlement and not as a country of asylum, that is, where refugees were selected by the state for entry and not where they self-selected. The argument is obviously self-serving. It serves to obscure the fact that Canada's emergence as a country open to refugee resettlement is of very recent vintage. The history of Canada bears a much longer witness to a country which deliberately kept out people on grounds of race and religion. Abella and Troper (1982) demonstrate that, as late as the post World War II period, that pattern was exercised to exclude Jewish refugees.

The argument for tradition errs in presuming that what is is what ought to be. A reverse argument can be made. What ought to be is indicated precisely by the historical pattern of what is presumed to be a given - such as the racial character of Canada or the assumption that Canada and Canada alone (through its civil servants) decides who can and who cannot enter. 
The historical precedent argument also utilizes a false opposition. For it is not the case, nor ought it to be the case, that a country is either a country of asylum or a country of resettlement. Thailand is a country of settlement and asylum. Canada does not deport Sri Lankans, for example, but, like Thailand, is responsible for leaving large groups of refugees in limbo. The either/or logic here is neither descriptive nor prescriptive.

But what about the issue of efficacy? Is it not more economical for Canada to select abroad rather than set up a very costly legal process for adjudicating a few claims? If three times as many people can be selected abroad at the same cost of processing one refugee on a self-selection principle, is this not far more cost effective per refugee?

Since existing procedures are cumbersome and lengthy, based as they are on a system designed to rule on deportation but then submitting that deportation ruling to multiple reviews, present cost comparisons are of little relevance. Cost comparisons would need to be made with a system set up from the start to process claims fairly and efficiently.

If after such reforms it still proved more costly to process a refugee claim within Canada than to select abroad, this would not justify eliminating the self-selection process. It would be like arguing we should never have trial by jury since trial by judge is more cost effective. Comparing an administrative procedure to one operating in a quasi-judicial way is inappropriate. The latter is an issue of law and right and not just benevolence. The first may be more cost effective, but it may deny protection to those in need who have the right to insist on such protection. But is this the case? Cannot a system built upon benevolence be fairer in that a self-selection system rewards males with the resources and initiative to get into the Canadian system? The selection system, it is argued, helps more refugees, and, further, helps more of those with greater needs than a self-selection system.

A few questions should be sufficient to undermine this argument. First, would a selection system in Guatemala and El Salvador have ever been started unless self-selected refugees had first arrived in Canada, alerting the government of the desperate situation there? Secondly, why does a selection system have to be seen as a substitute or alternative to a self-selection system - why are they not considered complementary? Thirdly, a self-selection system results in entry to significant numbers of legitimate refugees, even if a small percentage of the total; does this not suggest that it is important to retain a self-selection window of opportunity for those who cannot or will not take advantage of opportunities in their home countries? Those individuals who take the opportunity may indeed be the ones most at risk.

\section{Conclusion}

I have tried to indicate the shift in debate from viewing the issue of refuge versus asylum as an issue of temporary versus durable solutions to one of the principle of self-selectivity versus bureaucratic control. Secondly, I have tried 
to show that the justifications for absolute sovereign control which bureaucrats and states use to justify their restrictions on refugees is not based on selfinterest but may in fact be contrary to self-interest. In either case, the premise of absolute sovereign control over entry is a philosophical myth which does not accord with the philosophical premises of the liberal state. In fact, those premises dictate specific qualifications to that sovereignty.

I have not argued for self-selection instead of refuge, or suggested that selfselection has a higher moral value or is dictated by a higher sense of charity or mutual aid. In fact, I have tried to argue that qualified sovereignty which grants rights to refugees who are already within one's own country be established quite independently of the rival issues at stake based on the assumptions of a liberal state and on the qualifications and conditions attached to those premises.

Once the logic of the refuge versus asylum argument is undercut in favour of refuge plus asylum, the arguments of history, cost efficiency and mutual exclusivity to reinforce the idea of absolute sovereignty also begin to look very tenuous.

Agella, J. M:; and Troper, M. 1982 None is Too Many: Canada and the Jews of Europe, 1933-1948, Toronto, Lester and Orpen Dennys.

Dewirt, D. D., and KirTen, J. J. 1983 Canada as a Principal Power, Toronto, Wiley and Sons. Grahl-MAdsen, A. 1986 The Status of Refugees in International Law, Leyden, A. W. Sijthoff. GWYN, R. 1980 The Northern Magus: Pierre Trudeau and Canadians, Toronto, McClelland and Stewart.

LOESCHER, G., and SCANLAN, J. A., 1986 Calculated Kindness, Refugees and America's HalfOpen Door, 1945-Present, New York, Free Press.

STEIN, B., 1967 "The Nature of the Refugee Problem", paper presented at a conference on the International Protection of Refugees, Montreal, Canada.

STEIN, B. and CUNY, F., (forthcoming) "Prospects for Promotion of Spontaneous Repatriation", in Loescher, G. and Monahan, L. (eds.) Refugees in International Relations, Oxford University Press.

WALize, M. 1983 Spheres of Justice: A Defence of Pluralism and Equality, New York, Basic Books.

This article is to be published in a slightly different form as the introduction to an edited collection of essays on refuges and asylum entitled, Refuge or Asylum. Choice for Canada?, eds. Michael Lanphier and Lubomyr Luciuk. The publisher has not yet been announced. 